\section{B A Institute of \\ YK Business Administration \\ 六下 \\ Karachi \\ Leadership and Ideas for Tomorrow}

Business Review

Volume 5 Issue 2 July-December 2010

$7-1-2010$

\title{
Comparative study about English socio-economics factors of Pakistani universities students
}

\author{
Syed Umar Farooq \\ Allama Iqbal Open University Islamabad, Pakistan \\ Iqbal Shah \\ Allama Iqbal Open University Islamabad, Pakistan
}

Follow this and additional works at: https://ir.iba.edu.pk/businessreview

Part of the Economics Commons

\section{cc) (i)}

This work is licensed under a Creative Commons Attribution 4.0 International License.

\section{Recommended Citation}

Farooq, S. U., \& Shah, I. (2010). Comparative study about English socio-economics factors of Pakistani universities students. Business Review, 5(2), 159-166. Retrieved from https://doi.org/10.54784/ $1990-6587.1250$

This article is brought to you by iRepository for open access under the Creative Commons Attribution 4.0 License and is available at https://ir.iba.edu.pk/businessreview/vol5/iss2/10. For more information, please contact irepository@iba.edu.pk. 


\title{
DISCUSSION
}

\section{Comparative Study About English Reading Skills And Socio - Economic Factors Of Pakistani Universities Students}

\author{
Syed Umar Farooq \\ Allama Iqbal Open University Islamabad, Pakistan \\ Iqbal Shah \\ Allama Iqbal Open University Islamabad, Pakistan
}

\begin{abstract}
Learning materials written in English language often embarrass our students due to lack of the command over this imported language. As Pakistani Universities curriculum happens in English, therefore, the study will let us know the extent to which University students comprehend written English.

This paper will let us know whether different socio-economic factors affect the reading skill of English language. Further it will help the teachers and curriculum developer to look into such factors while teaching or developing English curriculum. It will also help the students to know about their English reading skill and work for its improvement in the light of findings. Further it will be helpful for the further researchers to work in the respective field.

Learning of material written in English language often embarrasses our students due to lack of command over the important language. Reading comprehension is today more important than it was in past because of the introduction of 'Information Technology' at the same time Pakistani students face a number of problems while reading text, written in English. The researcher therefore, conducted a research to evaluate the English reading comprehension of Gomal University, (D. I. Khan, Pakistan) students and relate it to different interesting factors. The study was meant to know whether socio-economic factors of the Gomal University students affect reading comprehension. The main objective of the study is to find the relationship between the socio-economic factors of the University students and their reading skills.
\end{abstract}

Key Words: Imported Language, Reading Skills , Socio-Economic Factors , Family Background

\section{INTRODUCTION}

The modern scientific research and technology has introduced a number of devices in our educational institutions like advanced computers. Now one can have very easy excess to foreign universities and scholars. But it does not mean that we should shun our traditional way of educational process, especially the skill of reading. Reading 
https://ir.iba.edu.pk/businessreview/vol5/iss2/10

DOI: https://doi.org/10.54784/1990-6587.1250

Business Review - Volume 5 Number 2

July - December 2010

comprehension is therefore, more important today than it was, in the past. We can communicate more effectively through Internet if we have better English comprehension. The educational process cannot proceed with a swift flow without better reading skills. Especially in our country, for higher education, when students confront with a foreign language like English, they need to know how to read purposefully; unfortunately the students are never taught the steps to improve their English reading. Moreover they ever do not try to learn it by themselves.

At the same time there are some socio-economic factors like poverty, malnutrition and its associated diseases, bad housing and parental unemployment etc. which may effect students reading comprehension. On the other hand if one has highly literate parents, less mental and physical strains and better facilities to read then one is likely to have a better approach in reading skill (Dechant, 1981).

In the meanwhile we have a totally different cultural and religious outlook as compared to English people. These differences are quite vivid in the structure and use of the two different languages.

The researcher will therefore, conducted a research a study to investigate Gomal University Students' competence in reading skill and to find its relation with socioeconomic factors and students' interests towards reading.

The results were generalized to the whole country, considering that all the universities have the same and equal facilities.

\section{READING}

Human beings have been reading for thousands of years, but attempts to describe the reading process are only fairly recent in history. The theorists and researchers from different fields of studies have speculated about reading process and learning to read process. There has also been long standing belief that reading is not a single basic skill. Reading is compiled intellectual and linguistic process, which should be developed throughout the life.

Reading is very complex process as it involves several factors, elements and skills. Although reading is individual activities, which help the reader to comprehend the writers', massage, the contents of the text and to enter the result, it has to be taken in silently or loudly.

In the opinion of Divid Eskey, "reading is difficult to take about or at least to say some thing informative about. As familiar a part of our every day lives as reading is for most of us, the true nature of the act remains oddly elusive.

What exactly is reading? What do we do when we read? And how can we teach someone else? How to do it? These are difficult questions because even scholars in field do not fully understand the process. 
https://ir.iba.edu.pk/businessreview/vol5/iss2/10

DOI: https://doi.org/10.54784/1990-6587.1250

Reading is no doubt a means of gaining knowledge. In the process of reading we receive information through the eyes, discriminating letter shapes, associating the letter with language, and associating the text with meaning. It is therefore quite clear that reading is cognitive process that demands a serious, careful and well-planned study of skill.

There are as many definitions of reading as there are experts in this particular area of learning. Some definitions of reading are given below:

i- $\quad$ Reading is an activity, which involves comprehension and interpretation of ideas symbolized by written and printed page.

ii- $\quad$ Reading is receiving communication. It is making the discriminative responses to graphics symbols. It is decoding graphic symbols.

\section{THE SOCIO-ECONOMIC PROBLEMS}

There are various factors involved in reading failure in Pakistan. These can be described as external ones.

One of the general concepts is that of social understanding. It is obvious that those students who belong to the low socio economic status are not the good readers. It is not specific to our own country it is a universal problem. For example when we study the work of a prominent educationist and psychologist of the west, Brute, he also declares poverty, malnutrition and its associated disease, poor hygiene, bad housing, unemployment and so on. Difficulty in learning is often associated with students' social background. We can deny this fact that one can get education in a better manner when one is economically sound and stable. As reading and education are correlated, so those students who belong to well bread famines are usually the best readers. Such students are mentally satisfied and can give proper attention to their study as their thoughts are focused on one aim i.e. to read. While the students from the low socio economic status have dispersed thoughts, which ultimately put diverse effect on their reading power.

Another factor in poor reading and comprehension of English is due to culture hostility. Culture has also its effect on reading. Our culture is entirely different from the Westerns culture. A particular class in our society has antagonistic attitude towards English. It is totally against this language. The people of this class want to uproot it from the country. So there exist two schools of thought in our country, one esthetically supports the English language and the other expresses its disgust against English. This thing once again has divided the readers into two categories, the supporters who are speeder readers and the antagonists who suffer from the flaw of halting during reading.

Another factor is that of choice. There is wide range of choice in selecting the language as a medium of instruction for our children at the elementary level. Their first 
https://ir.iba.edu.pk/businessreview/vol5/iss2/10

DOI: https://doi.org/10.54784/1990-6587.1250

Business Review - Volume 5 Number 2

July - December 2010

preference is to adopt their mother tongue as medium of instruction. So these students whose schooling have been done in Urdu when they reach the colleges and the universities, they face embarrassing problem with their curriculum which often happens to be in English. Due to owing lack of practice in English reading they spend weeks and months in comprehending the material in a proper manner. Ultimately they turn ready-made notes.

Another factor is the role of teacher community that is dismal and not promising and encouraging one. Very few teachers at the elementary level have sound command over English. Most of the teachers lack the competency to motivate the students.

The most important factor of reading failure in English is that of "English Phobia". Whether this language is difficult or not but we have taken it for granted as "the language beyond our access". An English book often embarrasses us.

In our society adequate reading ability is important as English has been assumed the first priority in jobs, researches an almost in media. The demand of citizenship in the modern world requires that we read and think critically. Indeed the mastery over this language will open up new chapters of knowledge.

It can be said with ought reading no effective learning can occure. As in Pakistan, the university curriculum is usually in English so it is necessary for our students that they should have proper command over English. If they will overcome the problems of reading then they will not only be able to understand the written material either in the text books or in magazine but they can also easily understand the lectures delivered in the class and can interact with their teachers. All this leads to enhance their comprehending power and mastery over the subject.

\section{SUMMARY}

Learning of material written in English language often embarrasses our students due to lack of command over the important language. Reading comprehension is today more important than it was in past because of the introduction of 'Information Technology' at the same time Pakistani students face a number of problems while reading text written in English.

The researchers therefore, evaluate the English reading comprehension of Gomal University Students and relate it to different interesting factors.

\section{OBJECTIVES OF THE STUDY}

The main objective of the study is to find the relationship between the socioecnomic factors of the University students and their reading skills. This main objective is partitioned into the following sub-objectives: 
1- $\quad$ To find out the correlation between vocabulary and comprehension.

2- $\quad$ To find the correlation between vocabulary and father education.

3- $\quad$ To find correlation between vocabulary and mother education.

4- $\quad$ To find the correlation between vocabulary and family income.

5- To find the correlation between socio-economic status of the selected students and their reading skill.

\section{METHODOLOGY}

All the post Graduate students of Gomal University were included in the study. Ideally, this kind of research requires randomly selected representatives but the researcher feared that some students might refuse to take the tests. Therefore the researcher took a convenient sample.

The test and questionnaire were given to the students in order to get the desired objectives. Three male and three female students of each department were given the test and questionnaire. The researcher kept a stopwatch in order to measure the reading time of the speed test. The whole data were tabulated and analyzed and conclusions were drawn on the basis of data.

\section{ANALYSIS}

TABLE - 1 SHOWING CORRELATION BETWEEN TEST ITEMS

\begin{tabular}{|c|c|c|c|c|c|c|c|}
\hline & $\begin{array}{c}\text { Vocabulary } \\
\text { Test }\end{array}$ & $\begin{array}{c}\text { Spelling } \\
\text { Test }\end{array}$ & $\begin{array}{c}\text { Punctuation } \\
\text { Test }\end{array}$ & $\begin{array}{c}\text { Sentence } \\
\text { Correction }\end{array}$ & $\begin{array}{c}\text { Comprehension } \\
\text { Test }\end{array}$ & $\begin{array}{c}\text { Total } \\
\text { Marks }\end{array}$ & $\begin{array}{c}\text { Speed } \\
\text { Test }\end{array}$ \\
\hline $\begin{array}{c}\text { Vocabulary } \\
\text { Test }\end{array}$ & & 0.61 & 0.14 & 0.05 & 0.30 & 0.81 & -0.41 \\
\hline $\begin{array}{c}\text { Spelling } \\
\text { Test }\end{array}$ & 0.61 & & 0.36 & -0.19 & 0.21 & 0.72 & -0.47 \\
\hline $\begin{array}{c}\text { Punctuation } \\
\text { Test }\end{array}$ & 0.14 & 0.36 & & 0.07 & 0.16 & 0.61 & -0.17 \\
\hline $\begin{array}{l}\text { Sentence } \\
\text { Correction }\end{array}$ & 0.05 & -0.19 & 0.03 & & 0.45 & 0.13 & 0.32 \\
\hline $\begin{array}{c}\text { Comprehension } \\
\text { Test }\end{array}$ & 0.30 & 0.21 & 0.61 & 0.13 & & 0.54 & 0.28 \\
\hline Total Marks & 0.81 & 0.72 & 0.61 & 0.13 & 0.45 & & -0.40 \\
\hline Speed Test & -0.41 & -0.47 & -.17 & 0.32 & -0.28 & -0.40 & \\
\hline
\end{tabular}


1. Table No. 1 shows that the correlation between vocabulary test and spelling is 0.61 , Which is substantial.

2. Table No. 1 shows that the correlation between vocabulary and total marks is 0.81 , which is very high.

3. Table 1 shows that the correlation between the spelling test and total marks is 0.72 , which is substantial.

4. Table 1 shows that the correlation between the punctuation test and total marks is 0.61 , which is substantial.

5. Table 1 shows that the correlation between the vocabulary and speed is 0.41 , which is negative.

6. Table 1 shows that the correlation between comprehension test and vocabulary is 0.30 , which is low.

TABLE -2 SHOWING CORRLETAION BETWEEN READING COMPREHENSION AND SOCIO-ECONOMIC FACTORS

\begin{tabular}{|c|c|c|c|c|c|}
\hline & $\begin{array}{c}\text { Vocabulary } \\
\text { Test }\end{array}$ & $\begin{array}{c}\text { Total } \\
\text { Marks }\end{array}$ & $\begin{array}{c}\text { Father's } \\
\text { Education }\end{array}$ & $\begin{array}{c}\text { Mother's } \\
\text { Education }\end{array}$ & $\begin{array}{c}\text { Family } \\
\text { Income }\end{array}$ \\
\hline Vocabulary & & & & & \\
Test & & 0.81 & -0.05 & 0.35 & 0.56 \\
Total Marks & 0.81 & & 0.02 & 0.15 & 0.53 \\
Father's & & & & & \\
Education & -0.05 & 0.02 & & 0.46 & 0.29 \\
Mother's Education & 0.35 & 0.15 & 0.46 & & 0.44 \\
Family Income & 0.56 & 0.53 & 0.29 & 0.44 & \\
\hline
\end{tabular}

1. Table 2 shows that the correlation between vocabulary and father education is -0.05 . It is negligible correlation.

2. Table 2 shows that the correlation between vocabulary test and mother education is 0.35 , which is low.

3. Table 2 shows that the correlation between vocabulary and family income is 0.56 , which is moderate.

4. Table 2 shows that the correlation between father education and total marks is 0.02 , which is negligible.

5. Table 2 shows that the correlation between total marks and family income is 0.53 , which is moderate. 
https://ir.iba.edu.pk/businessreview/vol5/iss2/10

DOI: https://doi.org/10.54784/1990-6587.1250

Business Review - Volume 5 Number 2

July - December 2010

\section{THE ANALYSIS OF DATA LED TO THE FOLLOWING FINDINGS}

The correlation between vocabulary test and spelling test is 0.61 , which shows that there is substantial correlation between the two variables.

The correlation between vocabulary and total marks is 0.8 , which is very high and shows that high vocabulary results in greater achievement of reading skill. The correlation between vocabulary and comprehension is 0.30 , which is low. The correlation between vocabulary and speed is -0.41 , which shows that mother tongue translation hinders in the speed of reading skill.

The correlation between spelling test and total marks is 0.72 , which is substantial and shows that correct spelling ability results in greater achievements of the reading skill.

The correlation between punctual and total marks is 0.61 , which is substantial and shows that punctuation skill can affect reading comprehension positively. The correlation between vocabulary and fathers' education is -0.05 , which is negligible and shows that educated fathers cannot spare for their children. The correlation between vocabulary and mother education is 0.35 , which is low but shows that educated mothers do affect the achievements in reading skills. Correlation between vocabulary and family income is 0.56 , which is moderate and shows that greater family facilities can affect skill positively.

Correlation between father education and total marks is 0.02 , which is negligible. It shows that educated fathers have been unable to spare time to their children. Correlation between total marks and family income is 0.53 , which is moderate. It shows that greater economic stability may result in greater achievements of reading skills.

\section{CONCLUSIONS}

1. Skills like vocabulary, spelling, punctuation and comprehension affect the reading skills.

2. Reading skill of the universities students is good.

3. Family income affects the reading skill positively.

4. University students are weak at punctuation.

5. Parental education, especially mother's education can improve student's reading ability.

6. Educated fathers do not find time to spare to their children, which affects their reading skills.

\section{RECOMMENDATIONS}

1. Skills like vocabulary, punctuation, spellings and speed etc. of the university students should be properly checked and if there is any deficiency it should be removed in time.

2. Students from the rural areas should be given due attention. 
https://ir.iba.edu.pk/businessreview/vol5/iss2/10

DOI: https://doi.org/10.54784/1990-6587.1250

Business Review - Volume 5 Number 2

July - December 2010

3. Arrangements should be made in central library of the Universities for the improvement of the four fold skills especially the reading skill.

4. Students are weak at punctuation. Therefore proper guidance should be given for the proper usage of punctuation.

5. Parents, especially fathers should spare time for their children and help them to guide in reading skill.

6. University should arrange for computers and other reading materials to the students who are financially weak.

7. Special optional classes for improvement of reading skill should be started; when students are properly evaluated and guided for the better improvements in reading skills.

8. Students should be given English equivalent meanings, otherwise the mother tongue may influence in reading speed.

\section{REFERENCES}

Anderson N. (1991). Individual differences in strategy use in second language reading and testing. Modern Language Journal, 75, pp. $460-472$.

Brooks G. Pugh A. and Schagen I. 1996. Reading Performance at Nine. Slough: NFER

Chun D. M and Plass J. L. 1996. Effect of multimedia annotations on vocabulary acquisition. Modern Language Journal, 80(2), pp. 183 - 198.

Clark M. M. 2004 International Studies of Reading, such as PIRLS - a cautionary tale, Education Journal, 75, pp 25-27.

Oxford, R. 1990. Language Learning Strategies: What every teacher should know. New York: Newbury House Publishers.

Thorndike R. L. 1973. Reading Comprehension Education in Fifteen Countries (IEA International Studies in Education 3). Stockholm: Almqvist and Wiksel.

Education does not mean teaching people to know what they do not know; it means teaching them to behave as they do not behave.

- Ruskin

166 